Asian J Agric \& Biol. 2021(3).

\title{
Assessment of aluminum tolerant of double haploid lines for developing new type of upland rice
}

\author{
Reny Herawati $^{*}$, Dwi Wahyuni Ganefianti ${ }^{1}$, Hesti Pujiwati1 ${ }^{1}$, Bambang Sapto Purwoko², Iswari Saraswati Dewi ${ }^{3}$ \\ ${ }^{1}$ Crop Production Department, Faculty of Agriculture, University of Bengkulu, Indonesia \\ ${ }^{2}$ Department of Agronomy and Horticulture, Faculty of Agriculture, Bogor Agricultural University, Indonesia \\ ${ }^{3}$ Indonesian Center for Agricultural Biotechnology and Genetic Resources Research and Development, Indonesia
}

\begin{abstract}
Received:
May 14, 2020

Accepted:

March 05, 2021

Online First:

April 02, 2021

Published:

July 07, 2021

\section{Abstract}

Aluminum can possibly have direct or indirect adverse effects on plant growth; however, this effect is not the same for all plants, even in the same species. The roots of plants are most sensitive to Al toxicity accompanied to initial symptoms such as the inhibition of cell extension and retarded development of root systems. This study was aimed to evaluate doubled-haploid (DH1) upland rice derived from anther culture to $\mathrm{Al}$ stress and to study the genetic diversity and population distribution of DH lines due to Al stress. Al tolerant test was carried out in a greenhouse using factorial Randomized Complete Block Design (RCBD) with three replicates. Yoshida nutrient solution containing $\mathrm{Al}$ of 0 and $45 \mathrm{ppm}$ was the first factor, while the second was the lines obtained from previous experiments (DH1), the four parents (SGJT36, SGJT28, Fatmawati, and Way Rarem), while Dupa, and ITA131, respectively as an Al tolerant and susceptible checks.. The results showed that root length, shoot length, and shoot dry weight had high heritability values and correlated well with the observed characters. Al tolerant doubled haploid upland rice lines derived from anther culture varied widely. Based on the Relative Root Length (RRL), out of 58 lines tested, 19 genotypes were highly tolerant, 29 lines were moderate, while 10 were low. The DH1 rice derived from P3 showed high, moderate, and low tolerance, while those from P6 showed high and moderate tolerance only.
\end{abstract}

Keywords: Aluminum (Al) tolerance, Doubled Haploid (DH), Upland rice lines.

\section{How to cite this:}

Herawati, R, Ganefianti, DW, Pujiwati, H., Purwoko, BS., and Dewi, IS, 2021. Assessment of aluminum tolerant of double haploid lines for developing new type of

upland rice. Asian J. Agric. Biol. 2021(3): 202005295. DOI: https://doi.org/10.35495/ajab.2020.05.295

This is an Open Access article distributed under the terms of the Creative Commons Attribution 3.0 License. (https://creativecommons.org/licenses/by/3.0), which permits unrestricted use, distribution, and reproduction in any medium, provided the original work is properly cited.

\section{Introduction}

The transition of land into residential areas, the construction of social facilities and infrastructure has led to a reduction in the field of agricultural land. It also resulted in the shifting of agricultural land to a marginal (dry land) area, especially on ultisol soils that reacted sourly to plant cultivation as a result of some symptoms such as lack of $\mathrm{Ca}, \mathrm{Mg}, \mathrm{P}, \mathrm{K}$, and $\mathrm{N}$ as well as the presence of $\mathrm{Al}$ toxicity. The high content of $\mathrm{Al}$ in acidic soil has shown to inhibit plant growth (Silva et al., 2010; Brunner and Sperisen, 2013). The 
utilization of acidic land is faced with various obstacles, such as low $\mathrm{pH}$, which reduces the availability of nutrients for plant growth. On the other hand, Al toxicity increases in very acidic soil $(\mathrm{pH}$ $<4.5$ ), with increasing Al solubility, which has detrimental effects on plants. Not only is the growth of rice roots inhibited, but also damaged by high concentrations of $\mathrm{Al}$ in the soil, which leads to significant reductions in rice yields (Ismail et al., 2007; Liu et al., 2012). The impact of $\mathrm{Al}$ is not the same on all plants, even in the same species.

The initial symptoms of Al toxicity in plants are inhibition of cell extension and the retarded development of root systems. Its availability in land solution depends on the level of soil acidity. In very acidic conditions ( $\mathrm{pH}<4.5)$, Al becomes very soluble, especially in the form of $\mathrm{Al} 3+$ ion, which is highly toxic to plants. It also interferes with the uptake, transport, and the utilization of nutrients, and also inhibits enzyme activity and hormonal balance (Lupwayi et al., 2014; Wan et al., 2019; Yamamoto, 2019). The high content of Al solution in the soil causes stunted root growth and decreases the ability of roots to absorb mineral and water nutrients (Silva et al., 2012; Ma et al., 2014; Kochian et al., 2015). The inhibition of root growth by $\mathrm{Al}$ occurs, due to cell division and elongation in the root meristem.

The accumulation of $\mathrm{Al}$ in root tissue determines the tolerance rate of plant genotypes, which correlate with the level of root damage. In tolerant genotype, the $\mathrm{Al}$ aggregation root was lower than the sensitive genotype (Ma, 2000; Zhang et al., 2019). The small number of negative charges on the cell wall in tolerant genotype reduces the interaction of $\mathrm{Al}$ with the root layer (Watanabe and Okada, 2005; Kochian et al., 2015). This phenomenon has also been reported in previous studies (Nursyamsi, 2000; Awasthi et al., 2017; Qian et al., 2018) that rice tolerance has a mechanism of reducing the interaction of $\mathrm{Al}$ on the root cell walls. Currently, many rice varieties have not tolerated acidic soils, and some are still being tested. High genetic diversity is one of the main factors used in improving plant traits, both by conventional and biotechnological methods. The previous study of genetic diversity on DH1 had produced 58 double haploid upland rice lines that were ready to be further evaluated (Herawati et al., 2009). Therefore, the proper selection needs to be done to obtain genotypes that tolerate aluminum stress. The differences in root growth character are one indicator that can be used in the tolerance selection, since roots are the main target of damage by Al. In upland rice, a quick method for evaluating genotypes that tolerate $\mathrm{Al}$ stress can be done by observing the root length in the vegetative phase (Bakhtiar et al., 2007; Belachew and Stoddard, 2017; Awasthi et al., 2017; Qian et al., 2018). This study aims to examine DH1 of upland rice derived from anther culture and also study genetic diversity, as well as the population distribution due to aluminum stress.

\section{Material and Methods}

The experiment was carried out in the greenhouse of the Indonesian Center for Research and Development on Biotechnology and Agricultural Genetic Resources, Cimanggu, Bogor. The materials used were 58 DH1 rice lines, the four elders (SGJT36, SGJT28, Fatmawati, and Way Rarem), Dupa, and ITA131 susceptible check (Prasetiyono, 2003; Bakhtiar et al., 2007).

Experiments using factorial Randomized Complete Block Design (RCBD) were repeated three times, with the Yoshida nutrient solution (Yoshida et al., 1976). A solution of aluminum at the concentrations of 0 and 45 ppm were given as the first factor, while the second was 64 rice line varieties.

The rice seeds were roasted for $3 \times 24$ hours at $45^{\circ} \mathrm{C}$ and sown on husk media. They were allowed to germinate in the dark for five days. After which those that were healthy and uniform with a height of $\pm 5 \mathrm{~cm}$ were selected for planting. The nutrient used was Yoshida solution with the final composition as follows: $40 \mathrm{ppm} \mathrm{N}$, ten ppm P, $40 \mathrm{ppm} \mathrm{K}, 40 \mathrm{ppm} \mathrm{Ca}$, 40 ppm Mg, 0.5 ppm Mn, 0.05 ppm Mo, 0.2 ppm B, $0.01 \mathrm{ppm} \mathrm{Zn}, 0.01 \mathrm{ppm} \mathrm{Cu}$, and two ppm Fe (Yoshida et al., 1976). In the $\mathrm{Al}$ treatment to reduce the formation of the polymer, the $\mathrm{pH}$ of the nutrient solution was adjusted to 4.5 by using $0.1 \mathrm{~N} \mathrm{NaHCO}$. After this, $2 \mathrm{ml}$ of Al solution made from $1000 \mathrm{ml}$ of $\mathrm{AlCl} 3.5 \mathrm{H} 2 \mathrm{O}$ was added to get a treatment concentration of $45 \mathrm{ppm}$. The $\mathrm{pH}$ of the nutrient solution was adjusted to $4.0 \pm 0.1$ with $0.1 \mathrm{~N} \mathrm{NaHCO} 3$ or $0.1 \mathrm{~N} \mathrm{HCl}$.

Five-day-old healthy sprouts from a uniform root were transferred to the media. Sprout stems were then wrapped in soft foam and placed on a nutrient solution in styrofoam holes. Each pothole was planted with five sprouts and maintained for 14 days in a greenhouse. A growth period of 14 days was used due to the composition of the Yoshida nutrient solution (Yoshida et al., 1976). During this phase, water addition and $\mathrm{pH}$ 
adjustment were carried out with $0.1 \mathrm{~N} \mathrm{NaHCO} 3$ or $0.1 \mathrm{~N} \mathrm{HCl}$ every two days. Observations were made on plants aged 14 days after planting, by measuring root length, plant height, root and shoot dry weight. The formula used to estimate the Shoot Root weight Ratio (SRR) was as follows:

$$
S R R=\frac{\text { root dry weight }}{\text { shoot dryweight }}
$$

The formula used to measure the variable Relative Root Length (RRL) was as follows:

$$
R R L=\frac{\text { root length under } A \text { l stress }}{\text { root length without } A l}
$$

Data analysis was performed using the Least Significant Difference Test (LSD). Tolerance of rice lines to $\mathrm{Al}$ stress were grouped into a susceptible $=$ $\mathrm{RRL}<0.5$, rather tolerance $=0.5<\mathrm{RRL}<0.70$, tolerance $=0.70<\mathrm{RRL}<0.85, \quad$ and highly tolerance $=\mathrm{RRL}>0.85$. Analysis of variance and the correlation between variables were performed using Pearson analysis and SAS software version 9.1. Genetic parameters were calculated based on the Singh and Chaudhary (1979) method as follows:

\begin{tabular}{|c|c|c|c|}
\hline $\begin{array}{c}\text { Source of } \\
\text { variance }\end{array}$ & df & Means Square & expectation value \\
\hline Genotipe & $(\mathrm{g}-1)$ & $\mathrm{M} 2$ & $\sigma_{e}^{2}+3 \sigma_{g}^{2}$ \\
\hline Error & $((\mathrm{r}-1)(\mathrm{g}-1)$ & $(\mathrm{M} 1$ & $\sigma_{e}^{2}$ \\
\hline
\end{tabular}

$\sigma_{e}^{2}=$ enviroment variance; $\sigma_{g}^{2}=$ genetic variance

$$
\sigma_{g}^{2}=\frac{M 2-M 1}{r} \sigma_{e}^{2}=M 1 \sigma_{p}^{2}=\sigma_{g}^{2}+\sigma_{e}^{2}
$$

The standard deviation formula for genetic variance:

$$
\sigma_{\sigma_{g}^{2}}=\sqrt{\left(\frac{2}{r}\right)\left[\left(\frac{M 2_{g}^{2}}{d f_{g}}+2\right)+\left(\frac{M 1_{e}^{2}}{d f_{e}}+2\right)\right]}
$$

M2 = Means squared genotype

M1 = Means squared error

$\mathrm{r}=$ replication

$\mathrm{dfg}=$ degree of freedom genotype

dfe $=$ degree of freedom error

Genetic diversity could be estimated from the genetic variance $(\sigma 2 \mathrm{~g})$ and the standard deviation of genetic variance $(\sigma \sigma 2 \mathrm{~g})$. A character had a broad genetic diversity when $\sigma 2 \mathrm{~g}>2 \sigma \sigma 2 \mathrm{~g}$. The Coefficient Genotype Diversity (CGD) was estimated using the formula as follows:

$$
C G D=\frac{\sqrt{\sigma_{g}^{2}}}{\bar{x}} \mathrm{x} 100 \% \overline{\mathrm{x}}=\text { average population observed }
$$

When $0<\mathrm{CGD} \leq 10.94$ (narrow); $0<\mathrm{CGD} \leq 21.88$ (narrower); $0<\mathrm{CGD} \leq 32.83$ (broader); $0<\mathrm{CGD} \leq$ 43.77 (broad); $43.77<$ CDG (broadest).

The Coefficient Phenotype Diversity (CPD) was estimated using the formula as follows:

$$
C P D=\frac{\sqrt{\sigma_{p}^{2}}}{\bar{x}} x 100 \%
$$

When $0<\mathrm{CPD} \leq 24.94$ (narrow); $0<\mathrm{CPD} \leq 49.71$ (narrower); $0<\mathrm{CPD} \leq 74.71$ (broader); $0<\mathrm{CPD} \leq$ 99.65 (broad); $99.65<$ CPD (broadest).

Heritability in a broad sense $\left(\mathrm{h}^{2} \mathrm{bs}\right)$ was calculated according to the formula:

$$
h_{b s}^{2}=\frac{\sigma_{g}^{2}}{\sigma_{p}^{2}}
$$

The heritability values (h2bs) were grouped according to Stanfield (1983) as follows:

$0.50<\mathrm{h} 2 \mathrm{bs}<1.00=$ high $; 0.20<\mathrm{h} 2 \mathrm{bs}<0.50=$ moderate; $\mathrm{h} 2 \mathrm{bs}<0.20=$ low.

Genotypic correlations were calculated using the formula:

$$
r_{g(x i j i)}=\frac{\operatorname{cov} \cdot g(x i x j)}{\sqrt{\left(\sigma_{g(x i)}^{2} \cdot \sigma_{g(x j)}^{2}\right)}}
$$

cov.g $(x i x j)=$ genotypic variation between properties $i$ and $\mathrm{j}$

$$
\begin{gathered}
\sigma_{g(x i)}^{2}=\text { genetic variability } \mathrm{i} \\
\sigma_{g(x j)}^{2}=\text { genetic variability } \mathrm{j}
\end{gathered}
$$




\section{Results and Discussion}

\section{Analysis of genetic diversity}

Analysis of variance of $\mathrm{DH} 1$ lines of rice with $\mathrm{Al}$ stress in nutrient culture showed significant differences in all observed variables (Table 1). Al stress reduced root length by 21.95 percent and shoots dry weight by 22.14 percent, while it decreased shoot length and root dry weight by only 6 percent (Figure 1).

Table-1. Analysis of variance of DH1 lines of new type upland rice under $\mathrm{Al}$ stress in nutrient solution

\begin{tabular}{|l|c|c|c|}
\hline \multicolumn{1}{|c|}{ Variable } & $\begin{array}{c}\text { Sum } \\
\text { Square }\end{array}$ & $\begin{array}{c}\text { Mean } \\
\text { Square }\end{array}$ & F value \\
\hline Root length & 1159.4 & 20.3 & $4.80^{* *}$ \\
Shoot length & 0.35 & 0.006 & $2.92^{* *}$ \\
Root dry weight & 0.089 & 0.0016 & $1.10^{*}$ \\
Shoot dry weight & 0.11 & 0.002 & $4.46^{* *}$ \\
Shoot root weight & 0.35 & 0.0062 & $2.92^{* *}$ \\
ratio (SRR) & & & \\
\hline
\end{tabular}

*Significant different at level 0.05 ; ** Significant different at level 0.01

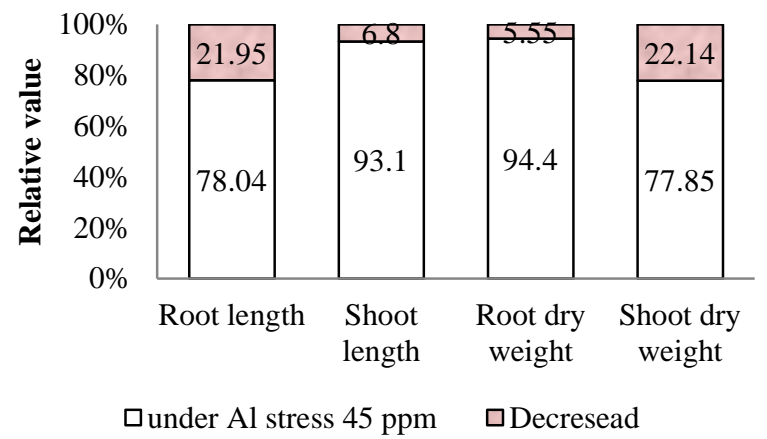

Figure-1. Effect of Al stress on variables of the length and dry weight of the root and shoot of DH1 lines.

The decrease in root length was caused by the obstruction of primary and lateral roots elongation. The field and laboratory experiments showed mixed responses to $\mathrm{Al}$ toxicity in rice (Watanabe and Okada, 2005; Bakhtiar et al., 2007; Qian et al., 2018). Reduction in shoot dry weight was due to the unavailable nutrients for suboptimal growth, as a result of the impaired mineral absorption and transport in roots (Kochian et al., 2015; Qian et al., 2018). The decrease in root dry weight was only 5.55 percent, compared to the dry shoot weight (22.14 percent) (Figure 1). Since the root length decreased and became shorter, therefore the adventitious roots grew the more.
These showed that under $\mathrm{Al}$ conditions, more carbohydrates were directed to root growth. Bakhtiar et al. (2007) and Belachew and Stoddard (2017) also observed that shoot dry weight was more sensitive to Al toxicity than root dry weight. The inhibition of shoot growth was a secondary effect due to nutrient deficiency, especially $\mathrm{Mg}, \mathrm{Ca}, \mathrm{P}$, and the restriction of water absorption, which caused dwarf rice growth (Ma et al., 2014). Wang et al. (2015) demonstrated that the application of $\mathrm{NH} 4$ decreased the $\mathrm{Al}$ content in rice roots by reducing the pectin content in their roots. Freitas et al. (2019) showed that aluminum chloride was more important in producing Al toxicity in the upland rice plants, grown in the nutrient solution.

Table-2. Genetic diversity of root and shoot length, root and shoot dry weight, and root shoot weight ratio under Al stress conditions

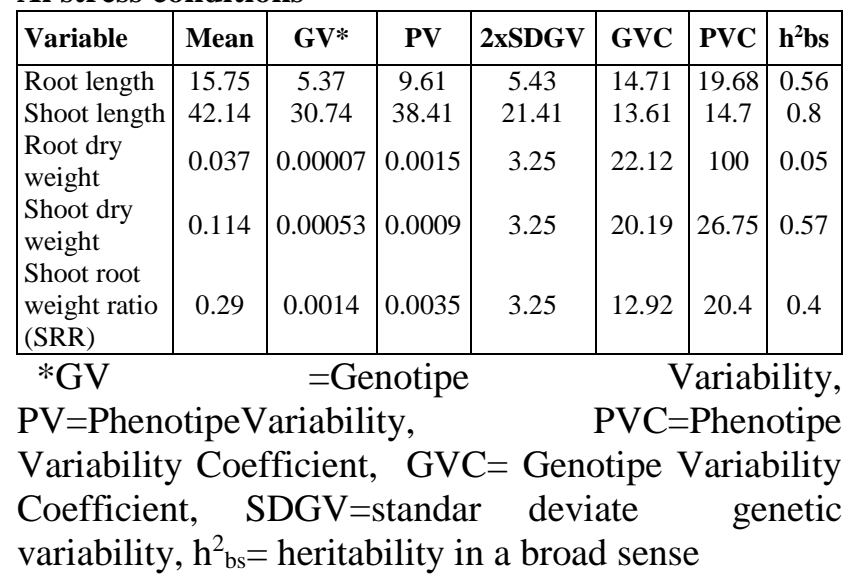

The estimated genetic parameters were shown in Table 2. Root length had a narrow diversity of genotypes with a broad coefficient of 5.37 and 14.71 percent. Shoot length had a broad genetic diversity that was 30.74 percent but had a narrow coefficient of 13.61 percent. Root dry weights both had a broad of the coefficient of genotypic diversity and coefficient of phenotype diversity (Table 2). The estimated heritability values of root and shoot dry weight were 0.05 and 0.8 , respectively (Table 2). The estimate for root length, shoot length, and shoot dry weight were considerably high. Characters that had high heritability values indicated that these genetic factors were more dominant than the environment; therefore, their selections were made in the first generation (Akinwale et al., 2011; Herawati et al., 2019).

Correlation and Relative Root Length (RRL)

Positive correlations were observed for all characters, 
except for shoot length and SRR, which showed negative (Table 3). Features that had significant differences and positive relationships were used as selection criteria. Root length, shoot length, and the shoot dry weight were selected as one of the requirements of $\mathrm{Al}$ tolerance for DH1 line. These characters had high genetic diversity, heritability values, and were positively correlated with other features.

Table-3. Correlation of root length, shoot length, root dry weight,shoot dry weight, and shoot root weight ratio (SRR) under Al stress condition

\begin{tabular}{|l|c|c|c|c|}
\hline \multicolumn{1}{|c|}{ Characters } & $\begin{array}{c}\text { Shoot } \\
\text { length }\end{array}$ & $\begin{array}{c}\text { Root dry } \\
\text { weight }\end{array}$ & $\begin{array}{c}\text { Shoot dry } \\
\text { weight }\end{array}$ & $\begin{array}{c}\text { Shoot root } \\
\text { weight } \\
\text { ratio (SRR) }\end{array}$ \\
\hline Root length & $0.42^{* *}$ & $0.28^{* *}$ & $0.53^{* *}$ & $0.12^{*}$ \\
\hline Shoot length & & $0.25^{*}$ & $0.65^{* *}$ & $-0.25^{*}$ \\
\hline Root dry weight & & & $0.43^{* *}$ & $0.11^{\mathrm{ns}}$ \\
\hline Shoot dry weight & & & & $-0.14^{*}$ \\
\hline
\end{tabular}

$*=$ significant at level $005 ; * *=$ very significant at level $001, \mathrm{~ns}=$ no significant

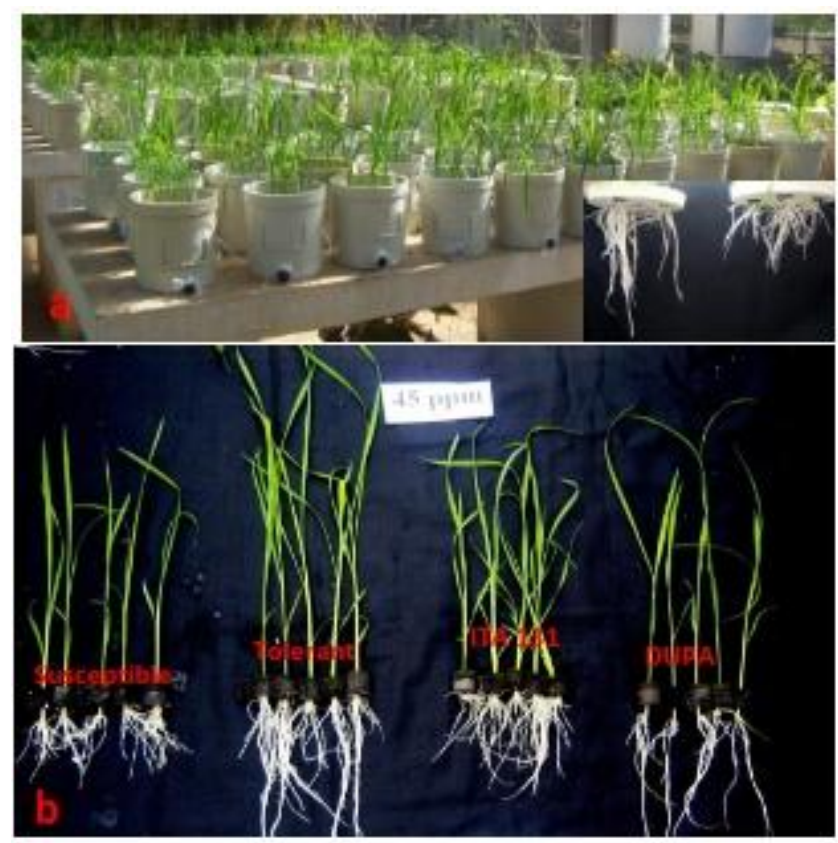

Figure-2. The experiment of Al stress on Yoshida nutrient solution (a); the root lengths of ITA 131 (susceptible check), and DUPA (tolerant check) under 45 ppm (b)
Among these characters, root length was more easily observed; therefore, the researchers used relative root length (RRL) to distinguish tolerant and Alsusceptible genotypes. Previous research indicated that the main target of $\mathrm{Al}$ toxicity was the root tissue of the plant. Root damage was characterized by decreased protein content in the cytoplasm and increased membrane damage to cell walls, which resulted in leakage (Zhu et al., 2018). Qian et al. (2018) reported that the fresh and dry weights of the rice seedlings were in significant correlation with chlorophyll content. This result indicated that a low Al concentration increased the seedlings' fresh and dry weights by increasing the leaf chlorophyll content and promoting photosynthesis.

Root shortening is one of the consequences of $\mathrm{Al}$ inhibition; therefore, its structure appeared to be shorter, fat, and reduced branching, while its adventitious roots grew the more (Figure 2a). The roots have hardy penetrating the soil layer also inhibit nutrients and water absorption. The toxicity level depends on the concentration of $\mathrm{Al}^{+3}$ ions in the soil solution. Al decreased the fresh weight by inhibiting the absorption of water and mineral substances (Qian et al., 2018).

The Relative Root Length (RRL) values for DH1 lines varied between 0.53-1.03 (Table 4). The RRL value of the Dupa (tolerant check) was 0.74, while ITA131 (susceptible check) was 0.53 (Figure 2b). The 5\% LSD test showed no significant difference between the RRL values for more tolerant genotypes and for susceptible checks (Table 4). This test corresponded with the previous experiments carried out by Prasetiyono (2003), Bakhtiar et al. (2007) that Dupa had tolerance at RRL value of 0.7 , however, for ITA131, it was 0.53 , which was found to increase from the previous test of 0.41 (Bakhtiar et al., 2007). For this reason, it was necessary to review using ITA varieties as susceptible checks (Figure 2b). The 5\% LSD test on DH1-lines resulted in 8 lines having significantly different higher RRL values than the Dupa check varieties $(\mathrm{RRL}=$ 0.74), such as line P6-274, P6-314, P3-196, P6-273, P6- 311, P6-250, P6-267, and P6-278 (Table 4). 
Reny Herawati et al.

Table-4. Root lengths in the treatments of 0 and 45 ppm Al with the Relative Root Length (RRL) value of DH1-lines at 14 days after planting

\begin{tabular}{|c|c|c|c|c|c|c|c|c|c|}
\hline \multirow[t]{2}{*}{ Lines } & $\mathbf{A \mathbf { l } _ { 0 }}$ & $\mathrm{Al}_{45}{ }^{1}$ & \multirow[t]{2}{*}{ RRL } & \multirow{2}{*}{ Criteria $^{2}$} & \multirow[t]{2}{*}{ Lines } & $\mathbf{A \mathbf { l } _ { 0 }}$ & $\mathbf{A l}_{45}$ & \multirow[t]{2}{*}{ RRL } & \multirow{2}{*}{ Criteria } \\
\hline & \multicolumn{2}{|c|}{$(\mathrm{cm})$} & & & & & & & \\
\hline P6-274 & 16.2 & 16.7 & $1.03^{*}$ & HT & P6-319 & 20.4 & 16.0 & 0.78 & $\mathrm{~T}$ \\
\hline P6-314 & 20.3 & 20.3 & $1.01 *$ & HT & P6-275 & 20.3 & 15.6 & 0.78 & $\mathrm{~T}$ \\
\hline P3-196 & 17.1 & 16.8 & $0.98 *$ & HT & P6-297 & 25.1 & 19.3 & 0.77 & $\mathrm{~T}$ \\
\hline P6-273 & 19.9 & 19.5 & $0.97 *$ & HT & P3-210 & 20.6 & 15.8 & 0.76 & $\mathrm{~T}$ \\
\hline P6-311 & 15.3 & 14.9 & $0.96^{*}$ & HT & P3-161 & 20.2 & 15.8 & 0.76 & $\mathrm{~T}$ \\
\hline P3-250 & 16.8 & 15.9 & $0.95^{*}$ & HT & P3-135 & 23.1 & 17.2 & 0.76 & $\mathrm{~T}$ \\
\hline P6-267 & 10.6 & 10.1 & $0.95 *$ & HT & P3-175 & 21.8 & 16.6 & 0.76 & $\mathrm{~T}$ \\
\hline P6-278 & 19.4 & 18.3 & $0.94 *$ & $\mathrm{HT}$ & P3-221 & 23.8 & 18.1 & 0.76 & $\mathrm{~T}$ \\
\hline P6-286 & 23.4 & 21.6 & 0.93 & HT & P3-190 & 20.2 & 15.3 & 0.75 & $\mathrm{~T}$ \\
\hline P6-266 & 12.5 & 11.7 & 0.93 & HT & P6-320 & 19.9 & 15.2 & 0.75 & $\mathrm{~T}$ \\
\hline P3-191 & 21.5 & 19.6 & 0.90 & HT & P3-162 & 20.9 & 15.4 & 0.74 & $\mathrm{~T}$ \\
\hline P6-264 & 14.0 & 12.6 & 0.90 & $\mathrm{HT}$ & P1-108 & 20.2 & 15.0 & 0.74 & $\mathrm{~T}$ \\
\hline P3-238 & 17.9 & 15.1 & 0.88 & HT & P6-317 & 16.3 & 12.2 & 0.73 & $\mathrm{~T}$ \\
\hline P3-204 & 17.2 & 15.1 & 0.88 & HT & P3-131 & 21.3 & 15.2 & 0.72 & $\mathrm{~T}$ \\
\hline P6-291 & 14.9 & 13.1 & 0.87 & $\mathrm{HT}$ & P3-248 & 18.7 & 13.5 & 0.72 & $\mathrm{~T}$ \\
\hline P6-265 & 12.4 & 10.9 & 0.87 & $\mathrm{HT}$ & P6-103 & 20.6 & 14.7 & 0.70 & RT \\
\hline P6-261 & 17.1 & 14.8 & 0.87 & $\mathrm{HT}$ & P3-160 & 24.2 & 16.8 & 0.70 & RT \\
\hline P6-257 & 20.6 & 17.8 & 0.86 & $\mathrm{HT}$ & P3-31 & 22.4 & 13.8 & 0.63 & RT \\
\hline P6-255 & 21.0 & 17.9 & 0.85 & HT & P3-26 & 23.7 & 14.6 & 0.61 & RT \\
\hline P6-276 & 20.1 & 16.9 & 0.85 & $\mathrm{~T}$ & $\mathrm{P} 4-45$ & 22.1 & 13.3 & 0.60 & RT \\
\hline P6-271 & 21.7 & 17.8 & 0.84 & $\mathrm{~T}$ & P5-50 & 22.1 & 12.9 & 0.59 & RT \\
\hline P3-148 & 20.9 & 17.3 & 0.83 & $\mathrm{~T}$ & P2-1 & 18.5 & 11.1 & 0.59 & RT \\
\hline P3-120 & 23.2 & 19.6 & 0.83 & $\mathrm{~T}$ & P3-27 & 25.7 & 14.0 & $0.54 *$ & RT \\
\hline P6-272 & 20.5 & 16.6 & 0.83 & $\mathrm{~T}$ & P2-2 & 18.5 & 10.1 & $0.54^{*}$ & RT \\
\hline P6-62 & 20.6 & 16.8 & 0.83 & $\mathrm{~T}$ & P3-28 & 23.9 & 12.7 & $0.53 *$ & RT \\
\hline P6-105 & 16.6 & 13.7 & 0.83 & $\mathrm{~T}$ & Dupa & 24.7 & 18.2 & 0.74 & $\mathrm{~T}$ \\
\hline P6-295 & 21.8 & 17.8 & 0.83 & $\mathrm{~T}$ & ITA131 & 21.1 & 11.3 & 0.53 & RT \\
\hline P3-159 & 24.5 & 19.9 & 0.81 & $\mathrm{~T}$ & SGJT-28 & & & 0.89 & HT \\
\hline P3-134 & 19.3 & 15.6 & 0.80 & $\mathrm{~T}$ & SGJT-36 & & & 0.86 & HT \\
\hline P3-150 & 21.9 & 17.6 & 0.80 & $\mathrm{~T}$ & W.Rarem & & & 0.52 & RT \\
\hline P6-302 & 20.3 & 15.5 & 0.79 & $\mathrm{~T}$ & Fatmawati & & & 0.76 & $\mathrm{~T}$ \\
\hline P3-158 & 24.1 & 19.2 & 0.79 & $\mathrm{~T}$ & BNT 0.05 & & & 0.2 & \\
\hline P3-249 & 20.6 & 16.3 & 0.78 & $\mathrm{~T}$ & KK (\%) & & & 15.69 & \\
\hline
\end{tabular}

*Significantly different from Dupa based on LSD 0.05 test; ${ }^{1} \mathrm{Al}_{0}=0 \mathrm{AlCl}_{3}, \mathrm{Al}_{45}=45 \mathrm{ppm} \mathrm{AlCl}_{3}$;

${ }^{2} \mathrm{HT}=$ Highly tolerant, $\mathrm{T}=$ tolerant, $\mathrm{RT}=$ Rather tolerant

In tolerance genotypes, $\mathrm{Al}$ was prevented from passing through the plasma membrane and entering the symplast and sites that were sensitive in the cytoplasm root tip. The ability of the root cell wall to absorb low $\mathrm{Al}$ and the permeability of its membrane were involved in the mechanism of external tolerance. Zhu et al. (2018) explained that Hydrogen sulfide $\left(\mathrm{H}_{2} \mathrm{~S}\right)$ played an essential role in $\mathrm{Al}$ stress resistance in plants. $\mathrm{H}_{2} \mathrm{~S}$ lowered $\mathrm{Al}$ toxicity by reducing its content in the apoplast and symplast rice root. Wang et al. (2017) showed that the activity of cytosolic glucose-6phosphate dehydrogenase was also involved in resistance to $\mathrm{Al}$ with the intervention of ROS levels in soybean. The result by Qian et al. (2018) indicated that $\mathrm{H}_{2} \mathrm{O}_{2}$ accumulation was also a key factor contributing to the decreased root activity.

In $\mathrm{Al}$ tolerance, plant $\mathrm{pH}$ was raised at the root tip (Kochian et al., 2004; Ma, 2007). This was due to the 
influx of $\mathrm{H}+$ around this area, which resulted in the deposition of $\mathrm{Al}$ and a decreasing $\mathrm{Al} 3+$ ion activity (Samac and Tasfaye, 2003; Zhao et al., 2014). High NO3- content in plants tend to reduce Al toxicity. It also caused the release of hydroxyl $(\mathrm{OH}-)$ or bicarbonate ions $\left(\mathrm{HCO}^{3-}\right)$ into the rhizosphere, increased $\mathrm{pH}$, and suppressed the solubility of $\mathrm{Al}$ (Justino et al., 2006; Zhao and Shen, 2018).

Table-5. The results of the DH1 lines selection for a new type of upland rice under $\mathrm{Al}$ stress

\begin{tabular}{|c|c|c|}
\hline Criteria & Genotype & $\begin{array}{c}\text { Number } \\
\text { of lines }\end{array}$ \\
\hline $\begin{array}{l}\text { Highly } \\
\text { tolerant }\end{array}$ & $\begin{array}{l}\text { P6: } 274,314,273,311,267,278,286 \\
266,264,291,265,261,257,255 \text {, dan } \\
\text { P3: } 196,191,238,204,250\end{array}$ & 19 \\
\hline Tolerant & $\begin{array}{c}\text { P6: } 276,271,272,62,105,295,302, \\
\text { 319, 275, 297, 320, 108, 317, dan P3: } \\
\text { 148, 120,159, 134, 150, 158, 249, 210, } \\
161,135,175,221,190,162,131,248\end{array}$ & 29 \\
\hline $\begin{array}{l}\text { Rather } \\
\text { tolerant }\end{array}$ & $\begin{array}{c}\text { P2: 1, 2; P3:160, 31, 26, 27, 28; P4-45, } \\
\text { P5-50, P6-103 }\end{array}$ & 10 \\
\hline
\end{tabular}

The RRL values of P3-27, P2-2, P3-28 were lower than the tolerant checks, and classified as the moderate tolerant genotypes (0.53-0.54), which was almost the same as the ITA susceptible checks (0.53) (Table 4). The grouping was based on the RRL values in 58 DH1-lines, tested on nutrient cultures at 0 and $45 \mathrm{ppm}$ $\mathrm{Al}$, and produced susceptible $=\mathrm{RRL}<0.5$, rather tolerant $=0.5<\mathrm{RRL}<0.70$, tolerant $=0.70<\mathrm{RRL}$ $<0.85$, and highly tolerant $=\mathrm{RRL}>0.85$, therefore, 19 highly, 29 tolerant, and 10 rather tolerant genotype were produced (Table 5).

Distribution of Population from Cross of P3 (Fatmawati $x$ SGJT-36) and P6 (SGJT-36 $x$ Fatmawati)

Aluminum tolerance was based on the Relative Root Length (RRL) and the Root Shoot weight Ratio (SRR) in DH1 populations from the crossing of P3 (Fatmawati $x$ SGJT-36) and P6 (SGJT-36 x Fatmawati) with the two parents were presented in Table 6. The Relative Root Lengths (RRL) in the P3 population ranged from $0.53-0.98$, while the P6 population ranged from $0.70-1.03$. The Fatmawati elders had an RRL value of 0.77 , while that of SGJT36 was 0.87 . There were diversities in all observed characters, with the SRR of the P3 population that ranged from 0.20 to 0.32 , while that of P6 graded from 0.22 to 0.39 . The Fatmawati elders had SRR values of 0.30, while those of SGJT-36 was 0.32 (Table 6).
Table-6. The Relative Root Length (RRL) and the Root Shoot weight Ratio (RSR) of DH1-lines in populations of crossing P3 (Fatmawati $x$ SGJT-36) and P6 (SGJT-36 $x$ Fatmawati)

\begin{tabular}{|l|c|c|c|c|c|}
\hline \multirow{2}{*}{ Characters } & \multirow{2}{*}{$\begin{array}{c}\text { X } \pm \\
\text { SD }\end{array}$} & \multicolumn{2}{c|}{$\begin{array}{c}\text { Range of DH1 } \\
\text { population }\end{array}$} & \multicolumn{2}{c|}{$\begin{array}{c}\text { Mean value of } \\
\text { parent ** }\end{array}$} \\
\cline { 3 - 6 } & DH1* & P3 & $\mathbf{P 6}^{* * *}$ & $\begin{array}{c}\text { Fatma } \\
\text { wati }\end{array}$ & SGJT-36 \\
\hline Relative Root & $0.8 \pm$ & $0.53-$ & $0.70-$ & 0.77 & 0.87 \\
Length (RRL) & 0.11 & 0.98 & 1.03 & 0.77 \\
\hline $\begin{array}{l}\text { Shoot Root weight } \\
\text { ratio (SRR) }\end{array}$ & $\begin{array}{c}0.29 \pm \\
0.04\end{array}$ & $\begin{array}{c}0.20- \\
0.32\end{array}$ & $\begin{array}{c}0.22- \\
0.39\end{array}$ & 0.30 & 0.32 \\
\hline
\end{tabular}

$* \mathrm{X} \pm \mathrm{SD} \mathrm{DH} 1$ is mean \pm standard deviate, **Fatmawati and SGJT-36 5 plants each,***P3 were 26 lines, and P6 were 27 lines

RRL and RSR values observed in DH1 populations varied greatly, some of which were similar to their parents, intermediates, and exceed both of their parents. The frequency distribution of P3 and P6 populations based on RRL values is presented in Table 7. Based on aluminum tolerance criteria, the frequency distribution of the two elders did not overlap. Fatmawati had tolerant criteria, while SGJT-36 had highly tolerant. The frequency distribution of DH1 populations of P3 derivatives was highly tolerant, tolerant, and rather tolerant, while the frequency distribution of P6 populations was highly tolerant to tolerant (SGJT-36 elders) (Table 7).

Table-7. Distribution of DH1 lines in each population of crossing P3 (Fatmawati x SGJT-36) and P6 (SGJT-36 x Fatmawati) based on aluminum tolerance

\begin{tabular}{|c|c|c|c|c|}
\hline \multirow{2}{*}{ Criteria } & \multicolumn{2}{|c|}{ Parent* } & \multicolumn{2}{c|}{ DH1** } \\
\cline { 2 - 5 } & Fatmawati & SGJT-36 & P3 & P6 \\
\hline Highly tolerant & 0 & $\sqrt{ }$ & 5 & 14 \\
\hline Tolerant & $\sqrt{ }$ & 0 & 16 & 12 \\
\hline Rather tolerant & 0 & 0 & 5 & 1 \\
\hline Susceptible & 0 & 0 & 0 & 0 \\
\hline
\end{tabular}

*The Fatmawati elders and SGJT-36 each with five plants, ** P3 were 26 lines, and P6 were 27 lines, $\sqrt{ } \mathrm{Al}$ tolerance criteria on elders

The frequent transgressive segregation in the anther of a plant produced lines with different tolerance levels. Few genes were observed to control $\mathrm{Al}$ acceptance levels in rice; therefore, not all genotypes possessed this gene. Zhang et al. (2019) found that there were significant differences between the gene expression patterns of Indica and Japonica Al-tolerant varieties. Therefore, the gene arrangement in the subgroups was 
similar to those in Japonica species. Each gene, or their combination, played a role in regulating the mechanism of Al-tolerance in rice and expressed in each phase of plant growth (Wu et al., 2000). Thus, the parent used in this study produced lines that were tolerant to aluminum stress. Therefore, further research was needed for the evaluation of leaf blast disease in the greenhouse to obtain the superior upland rice line.

\section{Conclusion}

The results of the evaluation of $\mathrm{Al}$ tolerance based on RRL in nutrient culture produced 19, 29, and 10 genotypic that was highly tolerance, tolerance, and rather tolerance, respectively. The tolerance level of $\mathrm{Al}$ in the DH1-lines of upland rice produced by anther culture varied significantly. The root length, shoot length, and the shoot dry weight had a high coefficient of diversity, heritability, and significantly correlated with each other. The distribution of $\mathrm{DH} 1$ populations of P3 derivatives produced highly tolerant, tolerant, and rather tolerant criteria, while those of P6 derivatives produced highly tolerant to tolerant only.

\section{Acknowledgement}

We would like to thank Yenni and Imam (staff at the Indonesian Center for Agricultural Biotechnology and Genetic Resources Research and Development) for their assistance in the Laboratorium and field works.

\section{Disclaimer: None.}

\section{Conflict of Interest: None.}

Source of Funding: None.

\section{References}

Akinwale MG, Gregorio G, Nwilane F, Akinyele BO, Ogunbayo SA and Odiyi AC, 2011. Heritability and correlation coefficient analysis for yield and its components in rice (O. sativa L.). Afr. J. Plant Sci. 5:207-212.

Awasthi JP, Saha B, Regon P, Sahoo S, Chowra U, Pradhan A, Roy A and Panda SK, 2017. Morphophysiological analysis of tolerance to aluminum toxicity in rice varieties of North East India. PLoSONE. 12(4):1-23 (e0176357). https://doi.org/10.1371/journal.pone.0176357
Bakhtiar, Purwoko BS, Trikoesoemaningtyas, Chozin MA, Dewi IS and Amir M, 2007. Penapisangalurpadigogohasilkulturanterauntukk etengganganaluminiumdanketahananterhadappe nyakitblas (Screening of Doubled Haploid Upland Rice Lines Generated from Anther Culture to Aluminum Tolerance). Bull. Agron. 35(1):8-14.

Belachew KY and Stoddard F, 2017. Screening of faba bean (Viciafaba L.) accessions to acidity and aluminium. PeerJ. 5:1-19 (e2963); DOI 10.7717/peerj.2963.

Brunner I and Sperisen C, 2013.Aluminum exclusion and aluminum tolerance in woodyplants. Front. Plant Sci. 4:1-12.

Freitas LB, Fernandes DM, Maia SCM, Moniz A, Mazziero BG and Steiner F, 2019. Sources and doses of aluminum in experiments with rice in nutrient solution. R. Bras. Eng. Agríc. Ambiental. 23(7):511-517.

Herawati R, Purwoko BS and Dewi IS, 2009. Keragaman genetik dan karakter agronomi galur haploid ganda padi gogo dengan sifatsifat tipe baru hasil kultur antera (Genetic diversity and agronomic traits of double haploid lines with the characteristics of new types upland rice derivated from anther culture). Jurnal Agronomi Indonesia. 37(2):87-93.

Herawati R, Masdar and Alnopri, 2019. Genetic analysis of grain yield of F4populations for developing new type of upland rice. SABRAO J. Breed. Genet. 51(1):68-79.

Ismail AM, Heuer S, Thomson MJ and Wissuwa $\mathrm{M}$, 2007.Genetic and genomic approaches to develop rice germplasm for problem soils. Plant Mol. Biol. 65:547-570.

Justino GC, Cambraia J, Olivia MA and Oliveira J, 2006. Uptake and reduction of nitrate in two rice cultivars in the presence of aluminum. Pesqui. Agropec. Bras. 41:1285-1290. DOI:10.1590/S0100-204X2006000800011

Kochian LV, Hoekenga OA and Pineros MA, 2004. How do crop plants tolerate acid soil? Mechanisms of aluminum tolerance and phosphorous efficiency. Annu. Rev. Plant Biol. 55: 459-493.

Kochian LV, Piñeros MA, Liu JP and Magalhaes JV, 2015. Plant adaptation to acid soils: the molecular basis for crop aluminum resistance. Annu. Rev. Plant Biol. 66:571-598. 
https://doi.org/10.1146/annurevarplant-043014114822

Liu J, Luo X, Shaff J, Liang C, Jia X, Li Z, Magalhaes J and Kochian LV, 2012. A promoter-swap strategy between the AtALMT and AtMATE genes increased Arabidopsis aluminum resistance and improved carbon-use efficiency for aluminum resistance. Plant J. 71: 327-337.

Lupwayi NZ, Benke MB, Hao XY, O’Donovan JT and Clayton GW, 2014. Relating crop productivity to soil microbial properties in acid soil treated with cattle manure. Agron. J. 106: 612-621.

Ma JF, 2000. Role of organic acids in detoxification of aluminum in higher plants. Plant Cell Physiol. 41:383-390.

Ma JF, 2007. Sindrome of aluminum toxicity and diversity of aluminum resistance in higher plant. Int. Rev. Cytol. 264: 225-252. DOI:10.1016/S0074-7696(07)64005-4

Ma JF, Chen ZC and Shen RF, 2014.Molecular mechanisms of $\mathrm{Al}$ tolerance in gramineous plants. Plant Soil. 381:1-12.

Nursyamsi D, 2000. Aluminum tolerance of tropical crops. MS.Thesis, Hokkaido University. Hokkaido, Japan.

Prasetiyono J, 2003. Identification of microsatellite markers that are linked to the tolerance properties of aluminum toxicity in crossing rice DUPA $x$ ITA 131 (Identifikasi marka mikrosatelit yang terpaut dengan sifat toleransi terhadap keracunan alumunium pada padi persilangan Dupa x ITA 131). MS Thesis, IPB (Bogor University), Bogor, Indonesia.

Qian L, Huang P, Hu Q, Qian Y, Xu S and Wang R, 2018. Morpho-Physiological Responses of An Aluminum-Stressed Rice Variety 'Liangyoupei 9'. Pak. J. Bot. 50(3): 893-899.

Samac DA and Tasfaye M, 2003. Plant improvement for tolerance to aluminum in acid soils. Plant Cell Tissue Organ Cult. 75:189-207.

Silva S, Pinto-Carnides, Martins-Lopes P, Mato M, Guedes-Pinto H and Santos C, 2010. Differential aluminum changes on nutrient accumulation and root differentiation in an $\mathrm{Al}$ sensitive vs. tolerant wheat. Eviron. Exp. Bot. 68:91-98.

Silva S, Pinto G, Dias MC, Correia CM, MoutinhoPereira J, Pinto-Carnide O and Santos C, 2012. Aluminium long-term stress differently affects photosynthesis in rye genotypes. Plant Physiol.
Biochem.

54:105-112. https://doi.org/10.1016/j.plaphy.2012.02.004

Stanfield WD, 1983. Theory and Problems of Genetics. 2nd edition. Schain's Outline Series. McGraw Hill Book Co. New Delhi, India.

Singh RK and Chaudhary BD, 1979. Biometrical Methods in Quantitative Genetics Analysis. Kalyani Publications, New Delhi, India. p.304.

Wang HH, Hou JJ, Li Y, Zhang YY, Huang JJ and Liang WH, 2017. Nitric oxide-mediated cytosolic glucose-6-phosphate dehydrogenase isinvolved in aluminum toxicity of soybean under high aluminum concentration.Plant Soil.416:39-52. doi: 10.1007/s11104-017-3197$\mathrm{x}$

Wang W, Zhao XQ, Chen RF, Dong XY, Lan P, Ma JF and Shen RF, 2015. Altered cell wall properties are responsible for ammoniumreduced aluminium accumulation in rice roots. Plant Cell Environ. 38: 1382-1390. DOI: 10.1111/pce. 12490

Wan WJ, Tan JD, Wang Y, Qin Y, He HM, Wu HQ, Zuo WL and He DL, 2019. Responses of the rhizosphere bacterial community in acidic crop soil to $\mathrm{pH}$ : changes in diversity, composition, interaction, and function. Sci. Total Environ.700: 134418. DOI: 10.1016/j.scitotenv.2019.134418

Watanabe T and Okada K, 2005. Interactive effects of $\mathrm{Al}, \mathrm{Ca}$ and other cations on root elongation of rice cultivars under low $\mathrm{pH}$. Ann. Bot. 95:379385.

Wu P, Liao CY, Hu B, Yi KK, Jin WZ, Ni JJ and He C, 2000. QTL and epistasis for aluminum tolerances in rice (Oryza sativa L.) at different seedling stages. Theor. Appl. Genet. 100:12951303. https://doi.org/10.1007/s001220051438

Yoshida S, Forno DS, Cock JH and Gomez KA, 1976. Laboratory Manual for Physiological Studies of Rice. IRRI $3^{\text {rd }}$ ed.

Yamamoto Y, 2019. Aluminum toxicity in plant cells: Mechanisms of cell death and inhibition of cell elongation. Soil Sci. Plant Nutr. 65(1):41-55. DOI: $10.1080 / 00380768.2018 .1553484$

Zhang P, Ding Z, Zhong Z and Tong H, 2019. Transcriptomic Analysis for Indica and Japonica Rice Varieties under Aluminum Toxicity. Int. J. Mol. Sci. 20(4): 997. DOI:10.3390/ijms 20040997

Zhu CQ, Zhang JH, Sun LM, Zhu LF, Abliz B, Hu WJ, Zhong C, Bai ZG, Sajid H, Cao XC and Jin QY, 2018. Hydrogen Sulfide Alleviates 
Reny Herawati et al.

Aluminum Toxicity via Decreasing Apoplast and Symplast Al Contents in Rice. Front. Plant Sci. 9:294. DOI:10.3389/fpls.2018.00294

Zhao XQ, Chen RF and Shen RF, 2014. Coadaptation of plants to multiple stresses in acidic soils. Soil Sci. 179:503-513.

DOI:10.1097/SS.0000000000000086

Zhao XQ and Shen RF, 2018. Aluminum-Nitrogen Interactions in the Soil-Plant System. Front. Plant Sci. $\quad 807$. https://doi.org/10.3389/fpls.2018.00807

\section{Contribution of Authors}

Herawati R: Conceived idea, designed research, methodology, collected and analysed data, manuscript writing

Ganefianti DW \& Pujiwati H: Literature review and data interpretation

Purwoko BS \& Dewi IS: Literature review, article write up 